\title{
Photosynthetic responses of selected Antarctic plants to solar radiation in the southern maritime Antarctic
}

\author{
Pedro Montiel, Andrew Smith \& Don Keiller
}

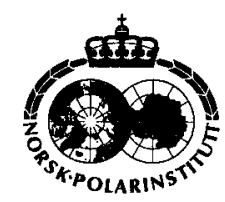

\begin{abstract}
The effects of UV-B exclusion and enhancement of solar radiation on photosynthesis of the two phanerogams which occur in the maritime Antarctic, Deschampsia antarctica and Colobanthus quitensis, and the moss Sanionia uncinata were investigated. Data on air temperature and solar radiation illustrate a drastic seasonal variation. Daily $\mathrm{O}_{3}$ column mean values and UV-B measured at ground level document the occurrence of the $\mathrm{O}_{3}$ "hole" in the spring of 1997, with a concomitant increase in UV-B. The grass, $D$. antarctica, exhibited a broad temperature optimum for photosynthesis between $10-25^{\circ} \mathrm{C}$ while photosynthesis did not saturate even at high irradiance. The high water use efficiencies measured in the grass may be one of the features explaining the presence of this species in the maritime Antarctic. The net photosynthesis response to intercellular $\mathrm{CO}_{2}\left(\mathrm{~A} / \mathrm{c}_{\mathrm{i}}\right)$ for D. antarctica was typical of a $\mathrm{C}_{3}$ plant. Exposure to a biologically effective UV-B irradiance of $0.74 \mathrm{~W} \mathrm{~m}^{-2} \mathrm{did}$ not result in any significant change in either the maximum rate of photosynthesis at saturating $\mathrm{CO}_{2}$ and light, or in the initial carboxylation efficiency of Rubisco. $\left(\mathrm{V}_{\mathrm{c}, \max }\right)$. Furthermore while ambient (or enhanced) solar UV-B did not affect photochemical yield, measured in the field, of C. quitensis and D. antarctica, UV-B enhancement did affect negatively photochemical yield in $S$. uncinata. In $D$. antarctica plants, exposure to UV-B at low irradiances elicited increased flavonoid synthesis. The observed effects of UV-B enhancement on the moss (decreased photochemical yield) and the grass (increase in flavonoids) require further, separate investigation.
\end{abstract}

P. Montiel, British Antarctic Survey, High Cross, Madingley Road, Cambridge CB3 OET, UK; A. Smith \& D. Keiller, Anglia Polytechnic University, East Road, Cambridge CB1 1PT, UK.

Summer climatic conditions in the Antarctic, together with the isolation from more northerly land-masses, restrict the vegetation in the maritime Antarctic to mosses, lichens, algae, cyanobacteria and to two vascular species: the pearlwort Colobanthus quitensis and the grass Deschampsia antarctica (Smith 1984). Evidence of climatic change in the Antarctic Peninsula includes an upward trend in summer air temperatures since the late 1940s (Smith 1994). Mean annual air temperatures have also increased by 0.022 to $0.067^{\circ} \mathrm{C}$ per year (King 1994). Since the mid1970s there has been a marked thinning of the stratospheric ozone layer over the polar regions (Farman et al. 1985), which has continued throughout the 1980s and 1990s (Jones \& Shanklin 1995). Climate change is likely to lead to shifts in species, communities and relative abundance of polar vegetation (McGraw \& Fetcher 1992). Without detailed knowledge of species physiology and ecosystem properties, such shifts will be difficult to predict.

Monitoring populations of both Antarctic vascular species over a 27 year period has revealed a significant increase in numbers of individuals and populations at two separate localities in the maritime Antarctic (Fowbert \& Smith 1994). In $D$. antarctica no specific adaptations to the Antarctic environment are evident in terms of reproductive strategies (Convey 1996), or the fatty acid composition of phospholipids and galactolipids in leaves and roots (Zuñiga et al. 1994). However, an inverse relationship of chloroplast to cell area index and temperature has been reported 
for $D$. antarctica along a climatic and latitudinal gradient (Jellings et al. 1983). More significantly, one previous study (Edwards \& Smith 1988) suggests that photosynthetic rates in both species approach $30 \%$ of their maximum at $0^{\circ} \mathrm{C}$. A much larger number of studies on the cryptogamic vegetation of the region exist, including photosynthetic measurements in both lichens (reviewed by Schroeter et al. 1997) and mosses (e.g. Davey \& Rothery 1996).

Cellular responses to extreme fluctuations in solar radiation, temperature and water status are likely to be critical to plant competitive balance (Larcher 1995). In Antarctic terrestrial biota these relationships remain largely unexplored. The biological effects of UV-B on vegetation can be direct or indirect; direct effects include DNA photodamage and physiological effects (reviewed by Caldwell et al. 1995). Although direct damage of Photosystem II has been widely documented (Bornman 1991; Nedunchezhian \& Kulandaivelu 1997), inhibition of photosynthesis by UV-B is more likely to be linked to $\mathrm{CO}_{2}$ fixation (Baker et al. 1997). Photoprotective responses to UVR include structural modifications and increased synthesis of UV-B absorbing compounds (Caldwell et al. 1995; Rozema et al. 1997).

Research into the biological effects of increased UV-B in the Antarctic has focused mainly on marine ecosystems (see Goes et al. 1994; Karentz 1994; Riegger \& Robinson 1997; Neale et al. 1998), with relatively few studies on photoprotective pigments of terrestrial macro-algae, mosses and cyanobacteria (e.g. Post 1990; Garcia-Pichel \& Castenholz 1991; Post \& Larkum 1993). The present study defined photosynthetic responses in $D$. antarctica and assessed whether the two vascular plants and the moss Sanionia uncinata were responsive to manipulation of the solar environment (chiefly UV-B exclusion and enhancement) under ambient conditions at Léonie Island.

\section{Methods}

Monitoring of solar radiation: At Rothera Station $\left(67^{\circ} 34^{\prime} 07^{\prime \prime} \mathrm{S}, 68^{\circ} 07^{\prime} 30^{\prime \prime} \mathrm{W}\right)$, in the south-western Antarctic Peninsula, a Bentham DM 150 scanning spectroradiometer has measured spectral global irradiance since 1997. Measurements are made from 280 to $600 \mathrm{~nm}$ with a step size of $0.5 \mathrm{~nm}$ and a resolution of $1 \mathrm{~nm}$. The same instrument is used to calibrate UV-A and UV-B sensors (Delta-T Devices Ltd., Cambridge, UK) and irradiance (Photosynthetically Active Radiation, PAR, 400-700 nm) quantum sensors (Skye Instruments Ltd., Powys, UK) which are part of a year-round, automated station at Léonie Island $\left(67^{\circ} 36^{\prime} \mathrm{S}\right.$, $68^{\circ} 20^{\prime} \mathrm{W}$ ), $9 \mathrm{~km}$ south-west of Rothera Station.

Field experimentation: All field experimentation was carried out on Léonie Island. The species selected included the two vascular plants $(D$. antarctica, C. quitensis) and the moss S. uncinata. These species are found co-existing in similar locations, are widespread along the Antarctic Peninsula and provide a representative contrast between vascular and cryptogamic life strategies. Plants were transplanted to a north-facing terrace, dominated by grass swards. Following acclimation (10 days), plastic screens were positioned to affect changes in solar UV radiation. The screens (Du Pont Polyesters Group, Middlesborough, UK) used included UV transparent (Perspex OXO-2), UV opaque (Perspex VE) and UV-B opaque but UV-A transparent (Melinex). UV-B enhancement (around 30\% of background solar levels) was provided by a UV-B lamp $(313 \mathrm{~nm}$ maximum, Cole-Palmer Instrument Company, London, UK) fitted with Sanalux glass panels to absorb UV radiation below $280 \mathrm{~nm}$. The UV-B lamp was positioned in such a way so as to provide uniform UV-B enhancement over the test area, whilst not shading any plant material from sunlight. This enhancement (square-wave addition) was given for $5 \mathrm{~h} \mathrm{day}{ }^{-1}$ around solar noon (13.00 local time). The UV-B lamp $(115 \mathrm{VAC}, 60 \mathrm{~Hz})$ was switched on only when irradiance exceeded $300 \mu$ moles $\mathrm{m}^{-2} \mathrm{~s}^{-1}$. Such an arrangement allowed a total of five contrasting treatments, namely ambient (direct sun), UV transparent, UV exclusion, UV-B exclusion only and UV-B enhancement.

Controlled environment experiments: Plants ( $D$. antarctica) were collected at Signy $\left(60^{\circ} 43^{\prime} \mathrm{S}\right.$, $45^{\circ} 38^{\prime} \mathrm{W}$ ) and Léonie islands and transported to the BAS headquarters (Cambridge, UK) where they were acclimated in growth chambers prior to experiments. Chamber temperatures were $15^{\circ} \mathrm{C} /$ $7^{\circ} \mathrm{C}$ for daily $16 \mathrm{~h}$ day $/ 8 \mathrm{~h}$ night cycles, respectively. These conditions were used throughout, with plants kept inside growth incubators under modified covers made from the same UV 

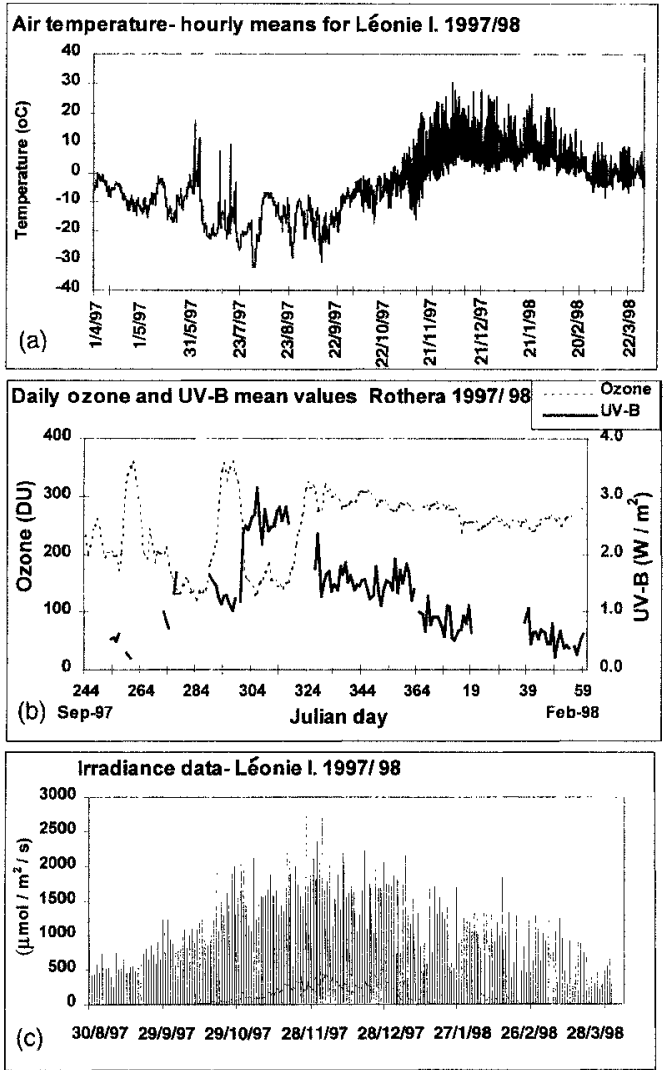

Fig. 1. Seasonal fluctuation in temperature, ozone and solar radiation at Rothera Station and Léonie I., 1997-98. (a) Air temperatures $(20 \mathrm{~cm}$ above ground) are hourly average of readings taken every $10 \mathrm{~min}$ (April 1997-March 1998). (b) Ozone column values and UV-B irradiance fluences (derived from scans from the Bentham spectroradiometer) are daily means (September 1997-March 1998). (c) Irradiance (photosynthetically active radiation, PAR) are values $(10 \mathrm{~min}$ intervals) from a quantum sensor $(400-700 \mathrm{~nm})$ (September 1997-March 1998).

transparent and opaque acrylic plastics as employed in the field studies. Typical irradiance in the growth cabinets was $150 \mu \mathrm{mol} \mathrm{m}^{-2} \mathrm{~s}^{-1}$, at plant level, while UV-B and UV-A was maintained at around 0.4 and $5.1 \mathrm{~W} \mathrm{~m}^{-2}$, respectively, with a daily weighed ("generalized plant action spectrum" by Caldwell [1971]; parametrized by Thimijan et al. [1978]) dose of $4.89_{\mathrm{BE}}$ $\mathrm{kJ} \mathrm{m}^{-2} \mathrm{day}^{-1}$ for a $16 \mathrm{~h} \mathrm{day}^{-1}$ cycle. Although the total irradiance in the growth cabinets was low compared to peak irradiance in the field (Fig. 1c), the ratio of UV-B/UV-A/PAR was similar to that measured in the field, in the absence of significant ozone depletion. It must be noted that in the Antarctic the high seasonal variation in irradiance (Fig 1; see also Davey \& Rothery 1996) combines with daily variation; high UV-B irradiances can occur at low irradiances during ozone hole events in early Spring (Webb 1997).

Photosynthetic gas exchange for D. antarctica: A Ciras-1 infra-red gas analyser (PP Systems Ltd., Herts., UK) was used, together with a microprocessor controlled cuvette which allowed complete control of leaf micro-environment variables $\left(\mathrm{CO}_{2}\right.$, temperature, irradiance and humidity). The Ciras-1 system allows simultaneous recording of photosynthetic and transpiration rates. Only the grass proved suitable for the automated cuvette. Water use efficiency (WUE) was calculated from $\mathrm{CO}_{2}$ and $\mathrm{H}_{2} \mathrm{O}$ exchange rates (Nobel 1991). Steady-state photosynthetic rate (measured after 7-8 min. equilibration for temperature and light response curves) was determined at an air flow rate of $300 \mathrm{ml} \mathrm{min}^{-1}, 345 \mathrm{ppm} \mathrm{CO}$, (unless $\mathrm{A} / \mathrm{c}_{\mathrm{i}}$ curves were collected) and $80 \%$ relative humidity $(5-6 \mathrm{mB})$. Attached $D$. antarctica leaves were used throughout. Temperature response curves (expressed as \% of maximum rate achieved per plant, so as to eliminate interplant variation caused by different leaf mass), were obtained (10-15 February 1998) from eight plants from three contrasting habitats: full sun (up to $1800 \mu \mathrm{mol} \mathrm{m}^{-2} \mathrm{~s}^{-1}$ ), partial sun (up to 1200 $\mu \mathrm{mol} \mathrm{m}{ }^{-2} \mathrm{~s}^{-1}$ ) and shade (up to $250 \mu \mathrm{mol}$ $\mathrm{m}^{-2} \mathrm{~s}^{-1}$ ). Irradiance was maintained at $1500 \mu \mathrm{mol}$ $\mathrm{m}^{-2} \mathrm{~s}^{-1}$ while cuvette and leaf temperature was increased stepwise from $2^{\circ} \mathrm{C}$ to $30^{\circ} \mathrm{C}$ and decreased similarly from $30^{\circ} \mathrm{C}$ to $2^{\circ} \mathrm{C}$. Light response curves were also measured using plants from the same contrasting environments; irradiance was increased stepwise from $0-1500 \mu \mathrm{mol} \mathrm{m} \mathrm{m}^{-2} \mathrm{~s}^{-1}$, following a $15 \mathrm{~min}$ dark acclimation, whilst leaf temperature was maintained between $15^{\circ} \mathrm{C}$ and $20^{\circ} \mathrm{C}$.

Photochemical efficiency: Chlorophyll fluorescence was used to monitor PSII photochemistry in undisturbed plants exposed to the different UV treatments. Measurements were made in the morning and again towards the end of the day period in order to evaluate any possible interaction between UV treatments and extended exposure to high irradiance. A portable OS100 modulated chlorophyll fluorometer (OptiSciences Inc, MA, USA) was used to obtain 


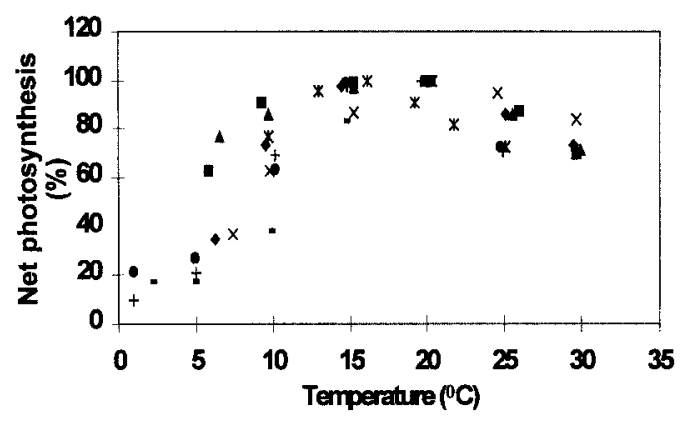

Fig. 2. Temperature response curves for net photosynthesis (\% of maximum rate achieved per plant;10-15 February 1998) in $D$. antarctica plants $(\mathrm{N}=8)$ from contrasting habitats, i.e. full sunexposed, partial sun-exposed and shade. Irradiance was kept at $1500 \mu \mathrm{mol} \mathrm{m}^{-2} \mathrm{~s}^{-1}$ while cuvette and leaf temperature was increased stepwise from $2^{\circ} \mathrm{C}$ to $30^{\circ} \mathrm{C}$ and decreased from $30^{\circ} \mathrm{C}$ down to $2^{\circ} \mathrm{C}$. The different symbols represent measurements for replicate plants.

steady-state yield values from undisturbed plants under field conditions. The fluorometer was used with a modified, $65^{\circ}$ open-body cuvette guide and an irradiance (PAR) sensor. Transplanted plants were "tagged" so that positioning of the fluorometer fiber optic tip on the same spots (4-5 per treatment) was reproducible throughout the experiments. Relative amplitude of the modulated light was set at 60 (vascular plants) and 70 (the moss) with a $0.8 \mathrm{~s}$ pulse duration.

Total flavonoid analysis by HPLC: Gradient HPLC analysis of flavonoids was performed on a Prodigy ODS3 column (Phenomenex, Cheshire, $\mathrm{UK})$, at $30^{\circ} \mathrm{C}$ with diode array detection. Plant tissue was ground in a pestle and mortar with cold $50 \%$ aqueous methanol containing $0.5 \%(\mathrm{v} / \mathrm{v})$

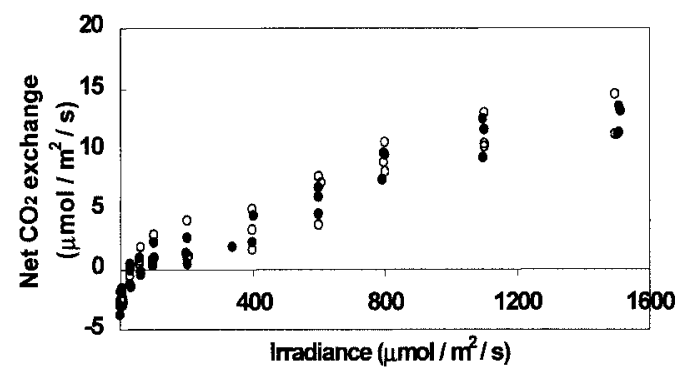

Fig 3. Light response curves for D. antarctica plants from contrasting habitats (open circles = full sun-exposed; filled circles $=$ shade). Irradiance was increased stepwise from $0-1500 \mu \mathrm{mol} \mathrm{m} \mathrm{m}^{-2} \mathrm{~s}^{-1}$ (dark acclimation for $15 \mathrm{~min}$ ). Leaf (and cuvette) temperature were kept between $15^{\circ} \mathrm{C}$ and $20^{\circ} \mathrm{C}$.

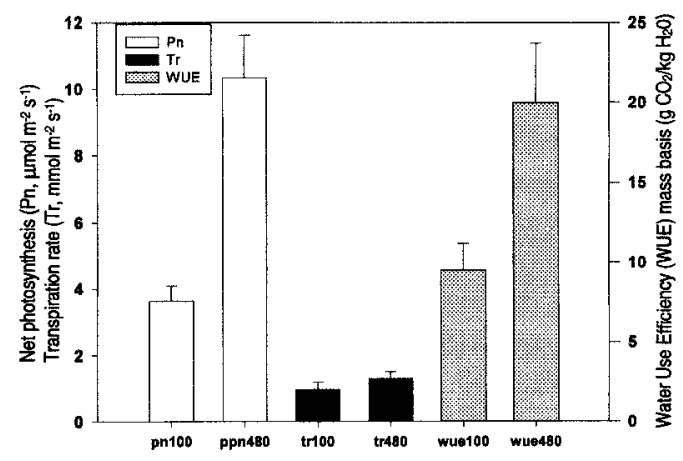

Fig. 4. Water Use Efficiency (WUE) for $D$. antarctica at two irradiance levels ( 100 and $480 \mu \mathrm{mol} \mathrm{m}^{-2} \mathrm{~s}^{-1}$ ) determined from net photosynthesis and transpiration data. Plants were collected from field locations and acclimated to growth cabinets. Growth cabinet conditions: temperatures of $15^{\circ} \mathrm{C} / 7^{\circ} \mathrm{C}$ for daily $16 \mathrm{~h}$ day/ $8 \mathrm{~h}$ night cycles, respectively.

glacial acetic acid, after which the extracts were centrifuged and passed through $0.45 \mu \mathrm{m}$ filters. Mobile phases included ammonium dihydrogen phosphate $(\mathrm{pH} 2.5)$ and absolute acetonitrile (Lunte 1987).

\section{Results}

Data on air temperature ( $20 \mathrm{~cm}$ above ground) and solar radiation illustrate a drastic seasonal variation (Figs. 1a, c). Daily $\mathrm{O}_{3}$ column mean values and UV-B (averaged from the Bentham scans) illustrate the occurrence of the $\mathrm{O}_{3}$ "hole" in the spring of 1997, with a concomitant increase in UV-B during November 1997 (Fig. 1b).

Photosynthesis measurements showed that $D$. antarctica had a broad temperature optimum (approximately $90 \%$ of the maximum) between $10-25^{\circ} \mathrm{C}$ (Fig. 2).

Photosynthetic rate response to irradiance revealed no saturation at high irradiance even in plants from shaded environments. Similarly there was very little difference in light compensation points between plants collected from the contrasting habitats (Fig. 3).

Apparent water use efficiency (WUE) was very high, with values ranging between 62 and $123 \mathrm{~mol}$ $\mathrm{H}_{2} \mathrm{O}$ per mol $\mathrm{CO}_{2}$; typical values for $\mathrm{C}_{3}$ species are between $300-500 \mathrm{~mol}_{2} \mathrm{O}$ per mol. Such efficiency, if confirmed in the natural environment, may partially explain the capacity of this species to 

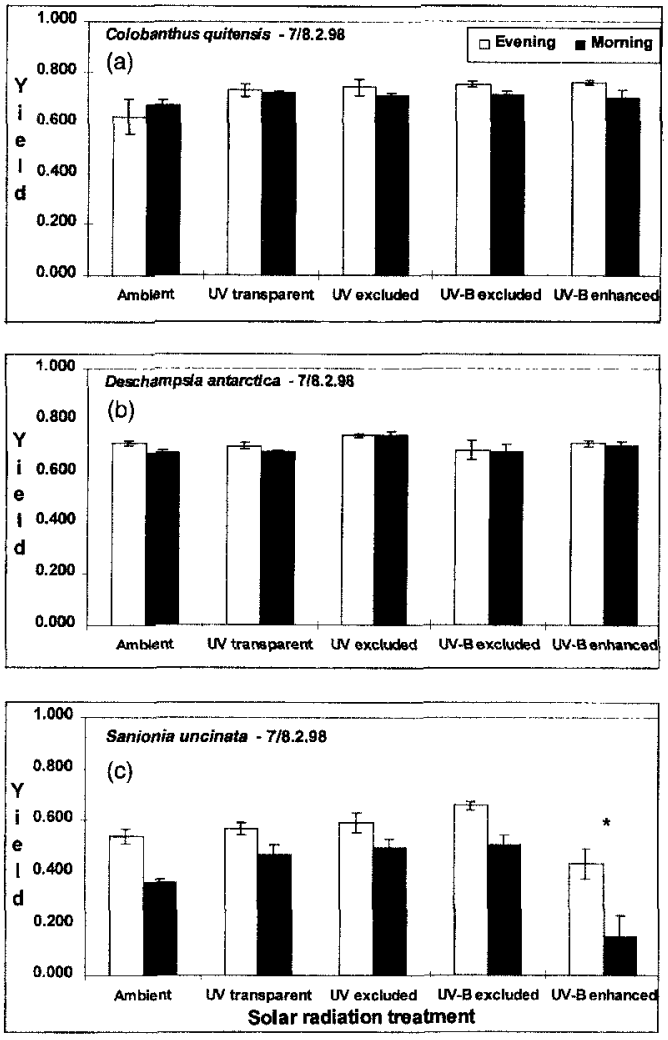

Fig. 5. Steady-state yield fluorescence parameter determined in the natural environment for (a) C. quitensis, (b) D. antarctica and (c) $S$. uncinata, following 7 days exposure to ambient conditions, total UV radiation exclusion, selective UV-B exclusion and UV-B enhancement (7-8 February 1998). Means $\pm 1 \mathrm{SE}$ are given. Measurements were carried out in the morning ( $10.00 \mathrm{~h}$, filled bars) and evening ( $19.30 \mathrm{~h}$, open bars). Statistical significance $\left(t\right.$-test, one-tail) is indicated $\left({ }^{*} \mathrm{P}<0.5\right)$ for the comparison of treatments vs ambient control.

survive in the cold semi-desert conditions of the maritime Antarctic (Fig. 4).

Chlorophyll fluorescence is used routinely as an intrinsic probe of photosynthetic function and as a screening tool for environmental stress tolerance, e.g. low temperatures (Öquist \& Huner 1993), dehydration (Casper et al. 1993), and UV-B (Vassiliev et al. 1994). For both phanerogams the data suggest that following an initial transient reduction in PSII yield, induced by UV-B enhancement (data not shown), there was no significant change in PSII efficiency (Figs. 5a, b). In contrast, a significant and sustained decrease in photochemical yield was recorded for the moss S. uncinata when exposed to enhanced UV-B (Fig. $5 c)$.

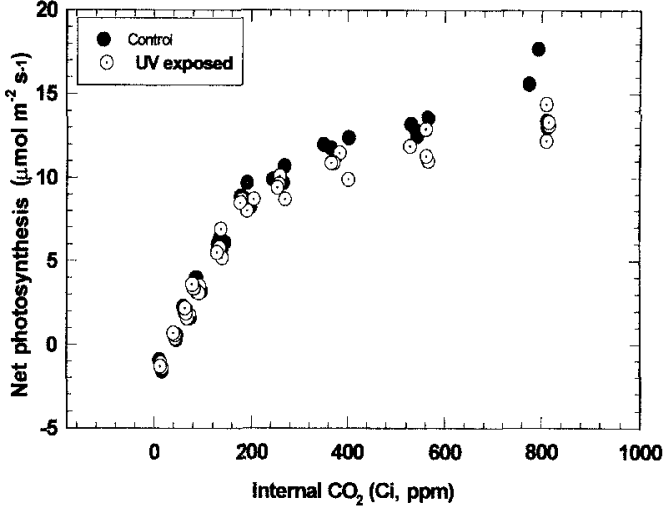

Fig. 6. $\mathrm{A} / \mathrm{c}_{\mathrm{i}}$ response curves (net photosynthesis response to intercellular $\mathrm{CO}_{2}$ concentration) for $D$. antarctica plants, maintained in controlled environment cabinets. and acclimated to UV-B exclusion or exposure (biologically effective irradiance of $0.74 \mathrm{~W} \mathrm{~m}^{-2}$ UV-B). Steady-state photosynthesis (measured after 7-8 min equilibration) was determined at an air flow rate of $300 \mathrm{ml} \mathrm{min}{ }^{-1}, 345 \mu \mathrm{l}^{-1} \mathrm{CO}_{2}$, and $80 \%$ relative humidity $(5-6 \mathrm{mB})$. Attached $D$. antarctica leaves were used throughout.

UV-B enhancement had little or no effect on the net assimilation response to intercellular $\mathrm{CO}_{2}$ concentration $\left(\mathrm{A} / \mathrm{c}_{\mathrm{i}}\right)$ in $D$. antarctica (Fig. 6).

HPLC analysis of $D$. antarctica shoots kept in controlled environments at low irradiances showed that total flavonoid were increased by exposure to UV-B, with some flavonoid species showing marked increases (peaks 1, 2, 3 and 7 in the overlay chromatograms; Fig. 7). The identity of these flavonoids requires further investigation.

\section{Discussion}

D. antarctica exhibited a typical $\mathrm{C}_{3}$-type response to temperature with a broad optimum. Optimal temperatures for net $\mathrm{CO}_{2}$ uptake are usually between $20^{\circ} \mathrm{C}$ to $35^{\circ} \mathrm{C}$ for $\mathrm{C}_{3}$ plants (Nobel 1991); thus the lower optimum for $D$. antarctica could be regarded as a specific adaptation. A wide optimum has the advantage that large daily fluctuations in temperature result in only small changes in photosynthetic rate (Larcher 1995). The data also confirmed that $D$. antarctica can sustain net photosynthesis (15-25\% of maximum rate) at temperatures approaching $0^{\circ} \mathrm{C}$ (Edwards \& Smith 1988). The response of net photosynthesis to irradiance indicate that light saturation did not occur at high irradiance even when using plants 


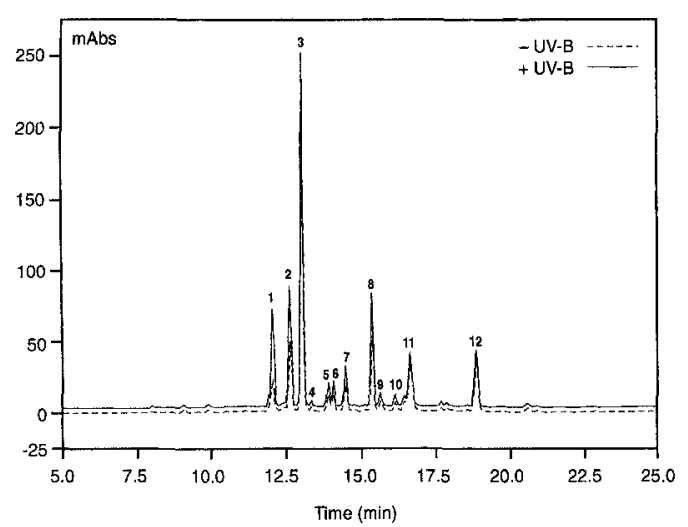

Fig. 7. Deschampsia antarctica. Overlay of chromatograms from two flavonoid extracts from tillers grown under conditions of low irradiances and where UV-B was excluded ( - UV-B) or allowed through (+UV-B) for 17 days. Plants were grown at $15^{\circ} \mathrm{C} / 7^{\circ} \mathrm{C}$ for $16 \mathrm{~h}$ day $/ 8 \mathrm{~h}$ dark daily cycles. Extracts were prepared using similar amounts of leaf material (around $20 \mathrm{mg}$ fresh weight) and injection of $60 \mu 1$ from equal dilution volumes.

from shade habitats. A high saturation point may allow fuller exploitation of the high irradiance levels experienced in the region during the growing season (Fig. lc), and may also serve as a protective mechanism against photoinhibition (Long \& Humpries 1994).

The gas exchange data, $\mathrm{A} / \mathrm{c}_{\mathrm{i}}$ response curves in particular (Figs. 2, 6), confirm that D. antarctica uses $C_{3}$-type photosynthesis (Sage 1994). However instantaneous water use efficiency (WUE) values were markedly higher than expected for a $\mathrm{C}_{3}$ grass. Comparable WUE values have been reported in both $\mathrm{C}_{3}$ and CAM succulents, from the Southern Namib desert, suggesting that some $\mathrm{C}_{3}$ plants can achieve high WUE values (Eller \& Ferrari 1997). It is hypothesized that the high WUE of the hair-grass may play an important role in the successful performance of the plant in an environment where free water is restricted.

The finding that UV-B exposure did not effect PSII photochemical yield in either vascular species (Fig. 5a and Fig. 5b) concurs with the emerging consensus that PSII damage is only manifested at high and unrealistic UV-B exposures (Allen, McKee et al. 1997; Allen, Nogués et al. 1998). Similarly, exposure to a biologically effective UV$B$ irradiance of $0.74 \mathrm{~W} \mathrm{~m}^{-2}$ (Caldwell-weighted), at a relatively low irradiance in growth cabinets, did not result in any significant change in either the maximum rate of photosynthesis at saturating $\mathrm{CO}_{2}$ and light $\left(\mathrm{J}_{\max }\right)$, or in $\mathrm{V}_{\text {c.max }}$. In contrast, Baker et al. (1997) reported significant reductions in both these parameters at UV-B irradiances of $0.63 \mathrm{~W} \mathrm{~m}^{-2}$. The responses of the vascular plants, in terms of photosynthesis and photoprotective pigments, to exclusion/enhancement of solar UV$\mathrm{B}$, indicates that current UV-B levels, experienced by $C$. quitensis and $D$. antarctica during the growing season, may not constitute a direct threat to photosynthetic activity. Furthermore, because of snow cover these species are unlikely to experience the elevated UV-B levels occurring during the spring $\mathrm{O}_{3}$ depletion event (Fig. 1c). The negative effect of UV-B enhancement on photochemical yield in the green moss $S$. uncinata requires further evaluation (Fig. $5 \mathrm{c}$ ).

This study has shown that exposure to enhanced solar UV-B irradiance elicited increased flavonoid production in $D$. antarctica (Fig. 7), thus sequestering energetic resources. Vegetation of the maritime Antarctic are slow growing, and subjected to numerous abiotic stresses, thus photoassimilate allocation may prove critical to survival. In Antarctic ecosystems particular attention should be paid to indirect plant responses to enhanced solar UV-B radiation; these are likely to affect competitive balance in species at the limits of their survival, with possible implications to biodiversity within ecosystems (Caldwell et al. 1995). It has been suggested that the current trend towards warmer growing seasons in the region will result in increased colonization by vascular plants (Fowbert \& Smith 1994). The results of this study support this hypothesis, as photosynthesis in these species appears to be well-adapted to current levels of solar irradiance and UV radiation.

Acknowledgements. - The authors wish to thank Dr. Helen Peat and Andrew Rossaak for processing micro-meteorological data, Dr. Brian Gardiner for providing the ozone column data and to Rothera Station personnel (A. Rossaak and P. Wickens in particular) for the logistical support that made the field work possible and enjoyable. The Melinex plastic used was a gift from the Du Pont Polyester Group (Wilton, Middlesborough, UK).

\section{References}

Allen, D. J., McKee, I. F., Farage, P. K. \& Baker, N. R. 1997: Analysis of the limitation to $\mathrm{CO}_{2}$ assimilation on exposure of leaves of two Brassica napus cultivars to UV-B. Plant, Cell Environ. 20, 633640.

Allen, D. J., Nogués, S. \& Baker, N. R. 1998: Ozone depletion and increased UV-B radiation: is there a real threat to photosynthesis? J. Exp. Bot. 49, 1775-1788. 
Baker, N. R., Nogués, S. \& Allen, D. J. 1997: Photosynthesis and photoinhibition. In P. J. Lumsden (ed): Plants and UV-B: responses to environmental change. SEB Series 64. Pp. 85-111. Cambridge: Cambridge University Press.

Bornman, J. F. 1991: UV radiation as an environmental stress in plants. J. Photochem. Photobiol. B: Biol. 8, 337-342.

Caldwell, M. M. 1971: Solar ultraviolet radiation and the growth and development of higher plants. In A. C. Giese (ed.): Photophysiology. Vol. 6. Pp. 131-177. New York: Academic Press.

Caldwell, M. M., Teramura, A. H., Tevini, M., Bornman, J. F., Björn, L. O. \& Kulandaivelu, G. 1995: Effects of increased solar ultraviolet radiation on terrestrial plants. Ambio 24, 166-173.

Casper, C., Eickmeier, W. \& Osmond, C. B. 1993: Changes in fluorescence and xanthophyll pigments during dehydration in the resurrection plant Selaniella lepidophylla in low and medium light intensities. Oecologia 94, 528-533.

Convey, P. 1996: Reproduction of Antarctic flowering plants. Antarct. Sci. 8, 127-134.

Davey, M. C. \& Rothery, P. 1996: Seasonal variation in respiratory and photosynthetic parameters in three mosses from the maritime Antarctic. Ann. Bot. 78, 719-728.

Edwards, J. A. \& Smith, R. 1. L. 1988: Photosynthesis and respiration of Colobanthus quitensis and Deschampsia antarctica from the maritime Antarctic. Br. Antarct. Surv. Bull. 81, 43-63.

Eller, B. M. \& Ferrari, S. 1997: Water use efficiency of two succulents with contrasting $\mathrm{CO}_{2}$ fixation pathways. Plant, Cell Environ. 20, 93-100.

Farman, J. C., Gardiner, B. G. \& Shanklin, J. D. 1985: Large losses of total ozone in Antarctica reveal seasonal $\mathrm{ClOx} / \mathrm{NO}$ interaction. Nature 315, 207-210.

Fowbert, J. A. \& Smith, R. I. L. 1994: Rapid population increases in native vascular plants in the Argentine Islands, Antarctic Peninsula. Arct. Alp. Res. 26, 290-296.

Garcia-Pichel, F. \& Castenholz, R. W. 1991: Characterization and biological implications of scytonemin, a cyanobacterial sheath pigment. J. Phycol. 27, 395-409.

Goes, J. I., Handa, N., Taguchi, S. \& Hama, T. 1994: Effect of $\mathrm{UV}-\mathrm{B}$ radiation on the fatty acid composition of the marine phytoplankter Tetraselmis sp.: relationship to cellular pigments. Mar. Ecol. Prog. Ser. 114, 259-274.

Jellings, A. J., Usher, M. B. \& Leech, R. M. 1983: Variation in the chloroplast to cell area index in Deschampsia antarctica along a $16^{\circ}$ latitudinal gradient. Br. Antarct. Surv. Bull. 61 , $3-20$.

Jones, A. E. \& Shanklin, J. D. 1995. Continued decline of total ozone over Halley, Antarctica, since 1985. Nature 376, 409-411.

Karentz, D. 1994: Ultraviolet tolerance mechanisms in Antarctic marine organisms. In C. S. Weiler \& P. A. Penhale (eds): Ultraviolet radiation in Antarctica: measurements and biological effects. Antarct. Res. Ser. 62, 93-110.

King, J. C. 1994: Recent climate variability in the vicinity of the Antarctic Peninsula. Int. J. Climatol. 14, 357-369.

Larcher, W. 1995: Gas exchange in plants. In W. Larcher: Physiological plant ecology. 3rd edition. Pp. 74-128. Berlin: Springer.

Long, S. P. \& Humpries, S. 1994: Photoinhibition of photosynthesis in nature. Ann. Rev. Plant Physiol. Plant Mol. Biol. $45,663-662$
Lunte, S. M. 1987: Structural identification of flavonoids in beverages by liquid chromatography with ultraviolet-visible and electrochemical detection. J. Chromatogr. 384, 371-382.

McGraw, J. B. \& Fetcher, N. 1992: Response of tundra plant populations to climatic change. In F. S. Chapin et al. (eds.): Arctic ecosystems in a changing climate: an ecophysiological perspective. Pp. 359-376. San Diego: Academic Press.

Neale, P. J., Davis, R. F. \& Cullen J. J. 1998: Interactive effects of ozone depletion and vertical mixing on photosynthesis of Antarctic phytoplankton. Nature 392, 585-589.

Nedunchezcian, N. \& Kulandaivelu, G. 1997: Changes induced by ultraviolet $(280-320 \mathrm{~nm})$ radiation to vegetative growth and photosynthetic characteristics in field grown Vigna unguiculata. Plant Sci. 123, 85-92.

Nobel, P. S. 1991: Physicochemical and environmental plant physiology. New York: Academic Press. 635 pp.

Öquist, G. \& Huner, N. P. A. 1993: Cold-hardening induced resistance to photoinhibition of photosynthesis in winter rye is dependent upon an increased capacity for photosynthesis. Planta 189, 150-156.

Post, A. 1990. Photoprotective pigment as an adaptive strategy in the Antarctic moss Ceratodon purpureus. Polar Biol. 10, 241-245.

Post, A. \& Larkum, A. W. D. 1993: UV-absorbing pigments, photosynthesis and UV exposure in Antarctica: comparison of terrestrial and marine algae. Aquat. Bot. 45, 231-243.

Riegger, L. \& Robinson, D. 1997: Photoinduction of UVabsorbing compounds in Antarctic diatoms and Phaecystis antarctica. Mar. Ecol. Prog. Ser. 160, 13-25.

Rozema, J., van de Staaij, J., Björn, L. O. \& Caldwell, M. M. 1997: UV-B as an environmental factor in plant life: stress and regulation. Trends Ecol. Evol. 12, 22-28.

Sage, R. F. 1994: Acclimation of photosynthesis to increasing atmospheric $\mathrm{CO}_{2}$ : the gas exchange perspective. Photosyn. Res. 39, 351-368.

Schroeter, B., Kappen, L., Green, T. G. A. \& Seppelt, R. D. 1997: Lichens and the Antarctic environment: effects of temperature and water availability on photosynthesis. In W. B. Lyons et al. (eds): Ecosystem processes in Antarctic ice free landscapes. Pp. 103-117. Rotterdam: Balkema.

Smith, R. I. L. 1984: Terrestrial plant biology of the subAntarctic and Antarctic. In R. M. Laws (ed.): Antarctic ecology. Vol. 1. Pp. 61-162. London: Academic Press.

Smith, R. I. L. 1994: Vascular plants as bioindicators of regional warming in Antarctica. Oecologia 99, 322-328

Thimijan, R. W., Carns, H. R. \& Campbell, L. E. 1978: Final report (EPA-IAG-D6-0168): radiation sources and relative environmental control for biological and climatic effects of UV research (BACER). Washington, D.C.: Environmental Protection Agency.

Vassiliev, I. R., Prasil, O., Wynam K. D., Kolber Z., Hanson, A. K. Jr., Prentice, J. E. \& Falkowski, P. G. 1994. Inhibition of PSII photochemistry by irradiance and UV radiation in natural phytoplankton communities. Photosyn. Res. 42, 51-64.

Webb, A. R. 1997. Monitoring changes in UV-B radiation. In P. J. Lumsden (ed.): Plants and UV-B: responses to environmental change. Pp. 13-30. Cambridge: Cambridge University Press.

Zuñiga, G. E., Alberdi, M., Fernandez, J., Montiel, P. \& Corcuera, L. J. 1994: Lipid content in leaves of Deschampsia antarctica from the maritime Antarctic. Phytochemistry 37, $669-672$. 